\title{
In this issue of food security - April 2021
}

\section{Serge Savary ${ }^{1}$}

Published online: 31 March 2021

(C) International Society for Plant Pathology and Springer Nature B.V. 2021

This April 2021 Issue of Food Security includes 15 very different articles coming from very different places in the world.

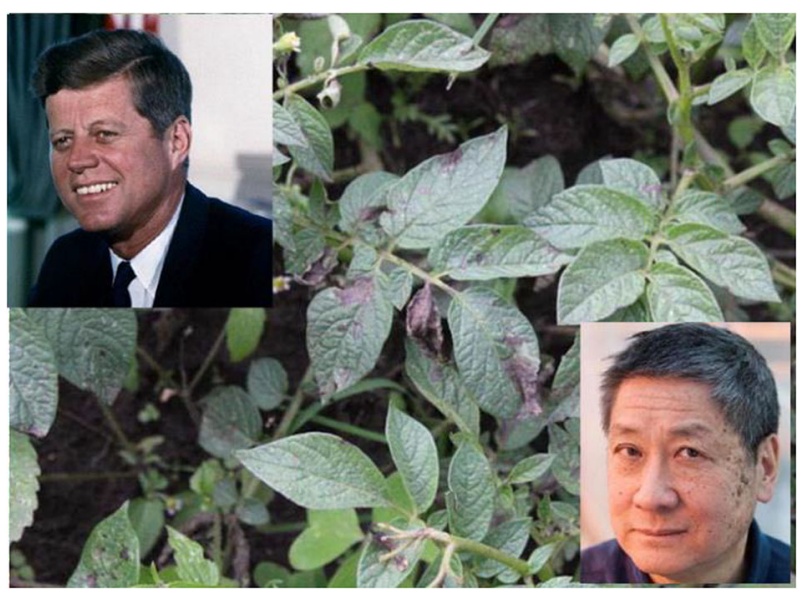

Photos from J. Yuen, this Food Security issue.

Serge Savary

serge.savary@inrae.fr

1 INRAE, l'Institut national de recherche pour l'agriculture, l' $^{\prime}$ alimentation et l'environnement, Auzeville, France
This issue starts with plant pathology and plant pathogens with a new article of the Series: "Plant Pathogens Which Threaten Food Security", launched with the Year of Plant Health of 2020.

- Article 1 is a review on the potato late blight and its pathogen written by Pr. Jonathan Yuen from SLU, Uppsala, Sweden. The article is part of the Series: Pathogens Which Threaten Food Security. In this article, J. Yuen provides us with an overview of the biological, as well as the economic, social, and political influence that Phytophthora infestans, the potato late blight pathogen, has had and still has. Those interested to know why and how a foreign pathogen introduced in Western Europe caused a famine in the nineteenth century, how in so doing it contributed to the Century of Revolutions, and how the potato late blight epidemic in Ireland is related with one famous president of the United States of America, are urged to read this article. 


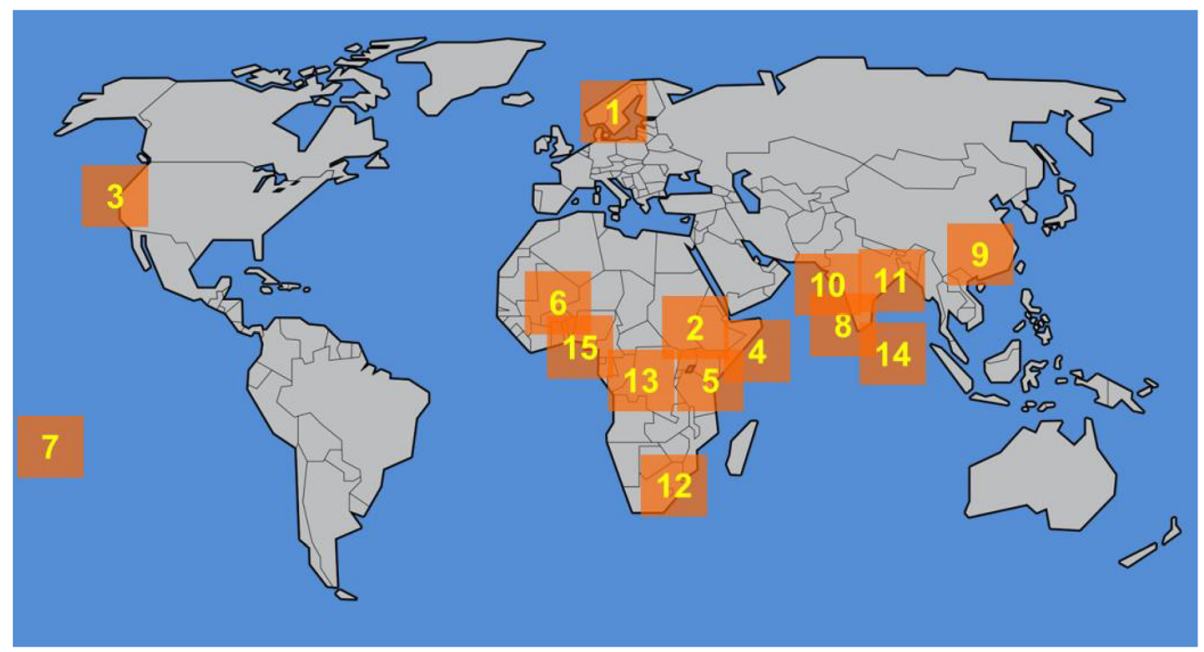

- The following two articles also deal with plant pathology. In Article 2, Elias Damtew et al. address the same plant disease from the standpoint of communicative intervention. In Article 3, Sara Garcia-Figuera et al. address the general questions of plant health as a collective good requiring collective action, across a range of crops and their diseases.

- The next two articles concern infrastructure that influence food security. Article $\mathbf{4}$ by Koyachew Enkuahone Kassie et al., addresses irrigation, and Article 5, by Adugna Eneyew Bekele et al., also in Ethiopia, considers large-scale investments for agro-pastoral systems.

- We have then a series of three articles related with nutrition. Article 6 is written by A. Lourme-Ruiz et al., and concerns the linkages between agricultural biodiversity and dietary diversity in Burkina Faso. Article 7, by John Paul Cauchi et al., also deals with nutritional diversity, in relation with community perceptions, in Kiribati. And Article 8, written by Deepthi E. Kolady et al., addresses the nutritional transition in India, via the food eaten "away from home".

- Article 9, by Li Jiang et al., addresses food production in the most populated country in the world, where the challenge remains to ensure food supply to everyone, now and in the future.

- The following five articles are related to climate change and its implications in terms of impacts and required adaptations. Article 10, by Chandra Sekhar Bahinipati, is a Review on farmers' adaptation in India, and Article 11, by Tiziana Pagnani et al., focuses on adaptive strategies of smallholders in Bihar. Article 12, by Abdoul G. Sam et al., addresses the effects of climate change on household welfare in Swaziland. The Review by Dong-Gill Kim et al., in Article 13, addresses the control of greenhouse gas emissions in small-holder farming in sub-Saharan Africa. The last article of the series, Article 14, by Dana Cordell et al., addresses the vulnerability of agrosystems towards climate change and phosphorus in Sri Lanka.

- This issue concludes with an economy article by Patrick L. Hatzenbuehler et al., titled: "Combining household and price data to target food marketing interventions in Nigeria". 